\title{
Does the Geographical Proximity Matter in Knowledge and Information Flow? A study about wine cluster in the Southern region of Brazil ${ }^{1}$
}

\author{
Janaína Ruffoni², Ana Lúcia Tatsch³, Rafael Stefani ${ }^{4}$, \\ Paola Rücker Schaeffer ${ }^{5}$ and Lenise Gessí Grings ${ }^{6}$
}

\begin{abstract}
This study aims to analyze technological knowledge and information flows intra and extra-cluster, as well as the cognitive roles the firms play. It was decided to investigate such flows among firms and institutions that compose the wine cluster of Vale dos Vinhedos, mountain region of Rio Grande do Sul, responsible for approximately $90 \%$ of the national wine production. The social network method was used for this article. As main results, it is highlighted: the information flow has a distinct dynamic from the technological knowledge flow established among firms; they play different cognitive roles in the identified technological knowledge network; great part of the connections established is with companies from the cluster itself; and the search for knowledge in support institutions in the area is intense, highlighting the importance of geographical proximity in the established relations.
\end{abstract}

Key-words: Innovation, knowledge and information flows, firms' cognitive roles, social network.

Resumo: O estudo tem como objetivo analisar os fluxos de informação e conhecimento tecnológico intra e extracluster, bem como os papéis cognitivos que as firmas desempenham. Optou-se por investigar tais fluxos entre firmas e instituições que compõem o cluster vinícola do Vale dos Vinhedos, região serrana do Rio Grande do Sul, responsável por aproximadamente $90 \%$ da produção

1. Data de submissão: 17 de junho de 2016. Data de aceite: 16 de junho de 2017.

2. Universidade do Vale do Rio dos Sinos (Unisinos). São Leopoldo, Rio Grande do Sul. Brasil. E-mail: janainart@gmail.com

3. Universidade Federal do Rio Grande do Sul (UFRGS). Porto Alegre, Rio Grande do Sul. Brasil. E-mail: analuciatatsch@gmail.com

4. Universidade Federal do Rio Grande do Sul (UFRGS). Porto Alegre, Rio Grande do Sul. Brasil. E-mail: rafstefani@gmail.com

5. Universidade Estadual de Campinas (Unicamp), Campinas, SP, Brasil E-mail: paolaschaeffer@ige.unicamp.br

6. Universidade do Vale do Rio dos Sinos (Unisinos). São Leopoldo, Rio Grande do Sul. Brasil. E-mail: lenisegrings@gmail.com 
nacional de vinhos. Foi utilizado o método de redes sociais. Como principais resultados, destacam-se: o fluxo de informação tem dinâmica distinta daquela do fluxo de conhecimento tecnológico estabelecido entre as firmas; essas desempenham diferentes papéis cognitivos na rede de conhecimento tecnológico identificada; grande parte das conexões estabelecidas é com empresas do próprio cluster; e é intensa a busca de conhecimento nas instituições de apoio existentes no local, destacando a importância da proximidade geográfica nas relações estabelecidas.

Palavras-chaves: Fluxos de informação, fluxos de conhecimento, cluster, inovação, vitivinícola.

JEL Codes: L25, L66, O3.

DOI: http://dx.doi.org/10.1590/1234-56781806-94790550309

\section{Introduction}

The geographical proximity is known as a relevant aspect to explain companies' innovative performance and competitiveness. Old contributions such as from Marshall (1890) and Perroux (1961) have already discussed the territorial dimension role in the organization of socioeconomic activities. Thenceforward, different investigation lines have emphasized the relation between geographical proximity, technological dynamism and competitive advantages.

Although many empirical studies have given support to this understanding and corroborated such view based on cases analysis, others highlight that the geographical proximity on its own does not determine a company's innovation capacity. That is due to there not being homogeneous knowledge flow on site. The knowledge asset is not easily available for every firm that belongs to a same cluster ${ }^{7}$ (MALMBERG and MASKELL, 2002; GIULIANI and BELL, 2005; MORRISON and RABELLOTI, 2009; RUFFONI and SUZIGAN, 2012, 2016; GIULIANI, 2013a, 2013b).

The knowledge flow is not diffused in the air; it does not even run freely among companies. The possibility of these companies betaking this knowledge, resultant from specific learning paths (DOSI, 1988; NELSON and WINTER, 1982), will depend on several structural characteristics. Among them, it is worth mentioning

7. In this article, the term 'cluster' was adopted not because of its theoretical skews, but because of its broad dissemination in international literature. these companies' size, specificities of products, technological intensity, lifetime, globalization and absorption capacity (COHEN and LEVINTHAL, 1990).

Giuliani and Bell (2005b) and Boschma (2005) reinforce this perception by stating that benefits arising from geographical proximity do not generate the same impacts on every firm in a homogeneous way. Knowledge and information diffuse through different mechanisms, being conditioned to the exploration, transformation and assimilation capacities, which internally characterize the companies. Therefore, even though formed by geographically proximate companies, with similar cultural characteristics and record, firms with distinct capacities compose the site. In the same way that even though it is constituted by firms from a certain sector or from correlative sectors, which refers to the idea of homogeneity, the clusters also have structural differences among them, besides being inserted in different contexts of competition (RABELLOTTI and SCHMITZ, 1999; GIULIANI, 2007).

Taking such considerations into account, the present study aims to analyze intra and extra cluster information and technological knowledge flows, as well as the cognitive roles the firms play. Howells and Bessant (2012), by pointing out the connections and knowledge flows present in clusters as new research fields, assist to justify the study object chosen here. Likewise, Giuliani (2013b) suggests new researches to advance in the understanding of actors' micro dynamics and their impacts over networks.

To perform such investigation, one particular cluster was selected and survey research was 
performed in its firms. We chose the wine cluster from Vale dos Vinhedos, in the mountain region of Rio Grande do Sul (RS), which is the state located in the extreme South of Brazil. This region covers $88 \%$ of RS's wineries and is responsible for about $90 \%$ of Brazilian wine production. ${ }^{8}$

The research was performed between June and July 2013 with firms from Vale dos Vinhedos. Vale dos Vinhedos was formed in the mid 90's from the foundation of Vale dos Vinhedos Wine Producers Association (Aprovale). Aprovale counts with 29 associated wineries, which represent $20 \%$ of $\mathrm{RS}^{\prime} \mathrm{s}$ fine wine production, besides 35 tourism-supporting enterprises. Vale dos Vinhedos was chosen as the object for this study due to its importance to the wine sector, the existing productive specialization and the institutionalism present there, whether they are teaching and research or representation organizations (FENSTERSEIFER, 2007; FARIAS and TATSCH, 2014). The wines produced at Vale dos Vinhedos are the only ones around the country to present the indication of origin and designation of origin seal (since 2002 and 2011, respectively), ${ }^{9}$ which are quality assurances of the wines produced there. ${ }^{10}$ Aprovale certifies the wines that comply with the quality standards required by these seals.

Added to these arguments that justify such choice, there is the possibility of comparing results from this

8. Tonietto et al. (2012) presents the characteristics of the wines produced in the mountain region of RS.

9. Sacco dos Anjos, Silva, Caldas and Pollnow (2014) report the trajectory of the experience in geographical indication in Vale dos Vinhedos.

10. For a discussion of the strategic roles of geographical indication see, for example, the work of Kohls, Sacco dos Anjos and Caldas (2016). Niederle and Aguiar (2013) affirm that during the social construction of quality catalyzed by the geographical indication conflicts emerge concerning the valorization of cultural goods and a modernization strategy for the regional wine production. Among the implemented innovations aiming to achieve the Indication of Origins for Vale dos Vinhedos, Jeziorny (2009) highlights: delimitation of the geographical area of production; restriction of wine products' set; determination of authorized cultivars' set; setting sensorial and chemical quality and identity patterns; limitation of maximum productivity per hectare; and creation of a distinct sign for the consumer. Besides, the author exposes the main impacts arising from this acknowledgement: on the marketing sphere, it is observed the arise in products' added value, as well as the demand's arise, while, on the territorial scope, it is analyzed the technological innovation response and the arise in the investments in the region. research to the ones from different empirical studies, based on the same theoretical perspective, also focused on wine clusters: in Canada (DOLOREUX and LORD-TARTE, 2013), Chile (GIULIANI and BELL, 2005a; GIULIANI, 2013b), Italy (MORRISON and RABELLOTTI, 2009) and South Africa (GIULIANI et al., 2010).

We believe, therefore, that this study will offer empirical evidences to contribute to the understanding of information exchange dynamics and knowledge in clusters.

This article is structured in four more sections, besides this introduction. In the second section, review of literature is elaborated, approaching the firm's innovative dynamic, the influence of the geographical proximity in this dynamic and the knowledge and information flows. In the third section the research methodology used is outlined, while in the fourth section we discuss the research results and, in the fifth and last section, the final considerations are presented.

\section{Literature review}

Based upon neo-Schumpeterian theoretical framework, it is concluded that innovative processes take place inside the firms, but in order for them to innovate, whether in product or in process, they rely not only on internal information sources (such as their sales departments, marketing, $R \& D$, and shop floor itself), but also on external sources. The latter comprises other companies, such as suppliers or competitors, research and teaching organizations, representation organizations, among others. Therefore, besides the internal factors related to organization, it is necessary to understand the innovation process's external factors, considering that firms do not operate in an isolated form, being inserted in an environment in which they transition and validate the internally developed solutions, considering that the firm that offers an innovative solution must be the one that obtains higher profits (FREEMAN, 1996; MALERBA, 1992; AMIN and WILKINSON, 1999).

Considering the importance of internal and external elements to firms, studies indicate the space, i.e. the site in which the company is located, as a source of competitive advantages that enhances the innovative dynamic of the firm. This advantage is 
directly related to the existence of a unique asset the Localized Knowledge Spillovers (LKS) -, which is considered fundamental to the innovations generation process, considering that this element allows the tacit knowledge to be transmitted among local actors (AUDRETSCH and FELDMAN, 1996; MORRISON and RABELLOTI, 2009).

The relation between the geographical proximity and the innovation generation by firms finds itself based on the concept of knowledge externality. Some studies that discuss this relation were based on assumptions presented by Marshall (1920), grounded on the existence of the marshallian externalities. The known trinity of marshallian externalities are: i) concentration of qualified and specialized labor; ii) existence of suppliers of goods and specialized services capable of attending to local demand; iii) spillovers of knowledge and technological processes that find themselves rooted on site.

It is attributed, then, to geographical and social proximity, the fact that ideas circulate more easily, promoting a collective and incremental process of innovation generation. In this direction, Giuliani (2013b, p. 1407) concludes, "the recombination of local skills and knowledge through social networking enables unique solutions, which, in many cases, are at the basis of firms' product differentiation and innovation strategies". Thus, the rooting of the firms in a particular territory is presented as a fundamental factor to innovation generation by firms.

In counterpart, Bathelt, Malmberg and Maskell (2004) and Boschma (2005) point out that the excess of geographical proximity and the existence of restricted flows on the internal scope of the cluster could be an obstacle to generate new ideas and information, which would cause an innovative tightness or lock-in, as designated in the literature. It is highlighted, therefore, the need for internal actors to maintain relations with external actors, in order to obtain additional assets, new market relations and new information sources, considering that successful clusters would be considered those that seek to keep the balance between the density of internal and external connections (MORRISON, RABELLOTTI and ZIRULIA 2013).

The cluster's external opening level is conditioned to firms' and institutions' absorption capacities, considering that the cluster's absorption capacity can be comprehended as the capacity to absorb, diffuse and explore knowledge provided by external actors (GIULIANI, 2002). With this settled, it infers that there is a cognitive distance between firms and external knowledge. Therefore, firms with higher absorption capacity may be those that have more connections with external sources, which makes them able to minimize the technological distance existing between the outside knowledge and the internally available knowledge in the cluster. On the other hand, it is possible to consider as a hypothesis that firms that maintain few relations, or position themselves in an isolated form in the group have lower absorptive capacity (we have considered the hypothesis of COHEN and LEVINTHAL, 1990; GIULIANI and BELL, 2005a).

Here it is necessary to inform the distinction adopted between information and knowledge. In this study we considered what some previews studies - Morrison and Rabellotti (2005a, 2005b), Giuliani and Bell (2005), Boschma and Wal (2005) and Ruffoni and Suzigan (2012) - in the area defined about this distinction: the information flow is understood as a flow of business information, that is, relative to the content of new commercial channels for firms' products, new suppliers, new technologies' types; and the knowledge flow refers to contents about the technological knowledge (tacit or codified) needed to solve technological problems and innovate.

Based upon this premise, it is analyzed that clusters do not absorb knowledge evenly, but in a selective form. Firms with smaller cognitive distance are responsible for broadcasting externally obtained knowledge, denominated technological gatekeepers. Gatekeepers maintain dense connections with the cluster's external actors and contribute to the diffusion of acquired knowledge, avoiding the risk of lock-in and exploring the advantages of geographical proximity for the diffusion of this knowledge (MORRISON, 2008; GIULIANI, 2011; MORRISON, RABELLOTTI and ZIRULIA, 2013).

Morrison (2008) analyzes that gatekeepers have the following characteristics: they constitute a small set of firms; they are the central part of an information network; they are exposed to external sources of information; and the connections established by them with external actors are predominantly informal. Besides, the author claims that for one to be considered a gatekeeper, the firm must, necessarily, have the ability to seek, decode and share information and knowledge 
externally obtained. The search activity comprehends the ability to externally capture knowledge that is relevant to the firm, while the decode function is related to the necessity to internally translate knowledge obtained from external sources and the sharing function refers to the ability to disseminate this knowledge to other firms from the cluster, considering that this knowledge transference only occurs when the relation is reciprocal and when the actors believe there will be a return for the shared knowledge. Ergo, in case the firms' knowledge basis is not distinct, the possibility of this transference will be restricted, i.e. the firm that has a larger basis of knowledge and information may behave in a reluctant form (LANE and LUBATKIN, 1998; MORRISON, 2008).

Giuliani and Bell (2005a), as a result of the investigation they performed in wine production companies in Chile, propose cognitive subgroups of firms and understand that such subgroups are representative of the form the cluster's knowledge system's dynamic is structured. These subgroups are:

a) Technological gatekeepers: firms that are in a central position in the network in terms of knowledge transference to other local firms and that are also strongly connected to external sources of knowledge;

b) Active mutual exchangers: firms that form the central part of the knowledge system, maintaining strong internal and external relations. Yet, they are less connected to extra-cluster agents than the technological gatekeepers;

c) Weak mutual exchangers: firms similar to active mutual exchangers, because they are relatively well connected to knowledge sources external to the cluster and because they have a balanced position of provision and absorption. However, they are less connected to other companies from the cluster;

d) External stars: firms that establish strong relations to external sources, but they have limited relations to the intra-cluster knowledge system;

e) Isolated-firms: firms weakly related to internal and external sources to the cluster.

Giuliani and Bell (2005b) highlight that interfirms interactions and learning are only possible when cognitive distance between them is not very significant. For example, it is possible to quote that "firms have more incentives to ask for technical advice when they know they will be able to decode and apply the received knowledge" (CARTER, 1989 apud GIULIANI, 2005b, p. 5). Based on the study by Cohen and Levinthal (1990) regarding absorption capacity of firms, the authors argued that firms with larger absorption capacity in a cluster are better suited to establish relations with knowledge sources external to the site.

Ruffoni and Suzigan (2015) performed a similar study to the one by Giuliani and Bell (2005a), however, applied to clusters from manufacturing companies of footwear machinery in Brazil and Italy. The authors identified different cognitive roles from each firm in the knowledge network, presenting a complementary typology:

a) Claimant: firm that only consults and is not consulted, i.e. appeals to the group to obtain knowledge, but is not requested as a knowledge source;

b) Absorber: firm that consults and is consulted, but requests technological knowledge more than it is requested;

c) Transmitter: firm that consults and is even more consulted by other firms;

d) Source: firm that is only consulted, hence the characterization as a 'technological knowledge source' and

e) Isolated: firm that does not participate in the knowledge network.

Following this line, later studies sought to investigate how these knowledge and information flows occurred among different types of firms. Among conclusions presented by Giuliani (2007), knowledge and information flows are significantly different, considering that the knowledge transference process is favored when firms belong to a common socialinstitutional context.

Morrison and Rabellotti (2009) corroborated these analyses by proposing that knowledge and information flows are structurally distinct, in the Italian wine clusters' situation, considering that the knowledge flow is limited to a set of firms that differ regarding their specific assets, from its innovative dynamic to its economical performance. Therefore, knowledge 
574 Does the Geographical Proximity Matter in Knowledge and Information Flow? A study about wine cluster in the Southern region of Brazil

cannot be considered something public, available to all that compose the cluster, but something that does not flow freely, "circulating into small 'epistemological communities'" (MORISSON and RABELLOTTI, 2009, p. 986).

Consequently, it is verified that information and knowledge flows are conditioned to some factors, among them: similar knowledge basis, close socialinstitutional contexts, high absorption capacity, reciprocity and trust relation in trades; considering these elements to be the ones that determine the position of each actor in the network.

Lastly, restricting the analyses to studies on wine sector clusters, Fenterseifer and Rastoin (2013) present four types of capitals present in clusters that may result in generation of competitive advantages to firms placed there. Among the capitals that were listed, it is verified: institutional capital, which comprehends public and private institutions responsible for coordinating collective actions, besides education system, research, training and technology available locally; specialization capital, which encompasses, mainly, the mashallian externalities, such as the presence of specialized suppliers; social capital, which comprehends the quality of social relations inside the cluster, basing itself on factors such as trust, the existence of shared values and reciprocity; reputation capital, which refers to the creation of a common identity to be perceived externally; and natural capital, referring to natural resources favorable to vitiviniculture activity, among which are highlighted weather, soil, water and landscape.

To close this section, still regarding wine segment studies, Board 1 synthesizes the main results found by authors that empirically investigate information and knowledge flows in clusters specialized in wine manufacturing in different countries.

Board 1. Synthesis of empirical studies that approach information and knowledge flows in wine clusters

\begin{tabular}{|c|c|c|}
\hline Author & $\begin{array}{l}\text { Location of the stu- } \\
\text { died object }\end{array}$ & Main Results \\
\hline $\begin{array}{l}\text { Giuliani and Bell } \\
(2005)\end{array}$ & $\begin{array}{l}\text { Cluster of Wine } \\
\text { Producers from Chile }\end{array}$ & $\begin{array}{l}\text { - The knowledge is real and flows among a determined group of companies } \\
\text { characterized by their high capacity of absorption. }\end{array}$ \\
\hline Giuliani (2007) & $\begin{array}{l}\text { Cluster of Wine } \\
\text { Producers from Italy } \\
\text { and Chile }\end{array}$ & $\begin{array}{l}\text { - Information and knowledge flows are significantly different, considering that } \\
\text { they are formed by different motivations; } \\
\text { - Information flow circulates in an uneven and selective way among firms. }\end{array}$ \\
\hline $\begin{array}{l}\text { Morrison and } \\
\text { Rabellotti (2009) }\end{array}$ & $\begin{array}{l}\text { Cluster of Wines from } \\
\text { Italy }\end{array}$ & $\begin{array}{l}\text { - Knowledge and information flows are structurally different; } \\
\text { - Knowledge circulates among groups restrict to firms that closely connected and } \\
\text { that differ in relation to others regarding their specific assets, their innovative } \\
\text { dynamic and their economical performance. }\end{array}$ \\
\hline $\begin{array}{l}\text { Farias and Tatsch } \\
\text { (2014) }\end{array}$ & $\begin{array}{l}\text { Wine Cluster from } \\
\text { the mountain region } \\
\text { of Rio Grande do Sul, } \\
\text { in the South of Brazil }\end{array}$ & $\begin{array}{l}\text { - The smaller wineries use more intensely information sources internal to the } \\
\text { region, specially information arising from production area of companies, besides } \\
\text { establishing a close relation with local suppliers; } \\
\text { - Larger companies use information available in several sources, both internal as } \\
\text { external to the cluster, more intensely. }\end{array}$ \\
\hline Giuliani (2011) & $\begin{array}{l}\text { Cluster of Wine } \\
\text { Producers from Chile }\end{array}$ & $\begin{array}{l}\text { - Technological Gatekeepers are firms responsible for acquiring knowledge } \\
\text { externally, i.e., out of the cluster's limits, to later on diffuse it internally for the } \\
\text { local firms. }\end{array}$ \\
\hline Giuliani (2013a) & $\begin{array}{l}\text { Cluster of Wine } \\
\text { Producers from Italy } \\
\text { and Chile }\end{array}$ & $\begin{array}{l}\text { - New products' development benefits from the cluster's shutdown towards } \\
\text { external sources; however, in long term, these benefits incur in loss of income; } \\
\text { - Level of openness of firms to external sources is more significant than the } \\
\text { connection network internal to the cluster to explain the firms' innovative } \\
\text { dynamics. }\end{array}$ \\
\hline Giuliani (2013b) & $\begin{array}{l}\text { Cluster of Wine } \\
\text { Producers from Chile }\end{array}$ & $\begin{array}{l}\text { - There is heterogeneity among firms towards accumulated resources and } \\
\text { capacities, which contributes for the formation of hierarchically structured } \\
\text { networks; } \\
\text { - Firms with higher capacities occupy privileged positions in local networks. }\end{array}$ \\
\hline $\begin{array}{l}\text { Doloreux and Lord- } \\
\text { Tarte (2013) }\end{array}$ & $\begin{array}{l}\text { Wine industry in } \\
\text { Canada }\end{array}$ & $\begin{array}{l}\text { - There is low collaboration with external sources; } \\
\text { - Industry is strongly connected to regional actors, which is due to local specificities } \\
\text { of vine production. }\end{array}$ \\
\hline
\end{tabular}

Source: Elaborated by the authors. 


\section{Methodological procedures}

The present study characterizes itself for being a theoretical-empirical research on which the Social Network Analysis (SNA) Method was used. According to Wasserman and Faust (2007), the pioneer studies in SNA area come from sociology, social psychology and anthropology. Evolution of investigations regarding this method contributed to the definition of concepts, graphical and mathematical representations, network types differentiation, procedures for data collection and different Statistics measures. 'Social Network Analysis: methods and applications', by Wasserman and Faust (2007), and 'Models and Methods in Social Network Analysis', by Carrington, Scott and Wasserman (2005) are important references.

Wal and Boschma (2007) analyzed SNA's application on economical geography and point out that network analysis presents a great potential to enrich researches on clusters. The authors report different methodologies for primary data collection (ex.: roster-recall) or for secondary data collection (ex: patents data). For this research, what matters are tools related to primary data collection. The Roster-recall tool is used when the whole actors' network is known. It consists in the fact that, for each actor from the network, a list of all the members is supplied, so that the actor mentions with whom they have a relation. An alternative method is the open roster, in which an open list of the actors is informed, and respondents may add others. A possibility to the study of the whole network is ego-network investigation, in which the network is assembled from egos' (actors) information, but, a priori, the network's full-size is not known or a thorough investigation is not possible due to its great dimension.

Besides these matters about types of data collection and network studies, in Wasserman and Faust (2007), there are explanations on various central concepts to networks analysis comprehension, which are: actor, relation between two actors, relation among three actors, subgroups inside the network, group and others. There are, also, different network categories: one-mode, two-mode and ego-network. The first one is the predominant type of analyzed network and it is characterized by the existence of a single group of actors (one-mode). Two-mode are networks that contain two groups of actors or one group of actors and one group of events. In addition, ego-network, previously mentioned, consists in a central actor (ego) and the relations it establishes with other actors. In the latter, it does not mean to analyze the whole-network, but the one identified from the ego's relations.

The choice of network type and relevant indicators will depend on the research goal and investigation possibilities on the chosen network. Some studies that applied the SNA method to analyze the relations between cluster's companies and institutions used onemode and two-mode categories, through the appliance of open roster or the roster-recall tool, and investigated the set of firms from the cluster, which is called 'wholenetwork' and possible due to the cluster's small size (i.e. few firms).

For Barabási (2002), a social network is composed by knots (or actors), connections and flows that are constantly in transformation. This interconnectivity presents a powerful form of network analyses and provides an investigation of connections' dynamic. Thus, unique analyses characteristics of social networks cause usual statistics tools to be inappropriate for certain analyses, indicating network models for an accurate observation. It was through the consideration of such characteristics from the social network's analysis method, that it was decided to apply it in the research presented here.

Data gathering was performed based upon primary data from only one group of actors (onemode), taking into consideration that the investigation took place in the whole network (whole-network). The activities performed for the execution of the research were diverse and are organized in four consecutive stages:

- Stage 1: in order to enable the proposed research, the register of the wine companies in the mountain region of Rio Grande do Sul from Brazilian Institute of Wine (Ibravin) was used, which is composed by 735 companies from Rio Grande do Sul's wine sector in 2012. Out of the necessity to frame the companies' sample to be investigated in the survey and to better know the sector, an exploratory stage was performed. In this stage, two specialists from the sector were interviewed, both from Rio Grande do Sul's Federal Institute (IFRS), and authors of the wine cluster investigated here. Face-to-face interviews were carried out, 
based on semi-structured script. As guiding questions, it was aimed to identify the role of firms and institutions that compose the cluster, being possible to map companies that occupy a technological leadership position (which in the survey research stage were interviewed and identified in this article by codes F4, F13, F14 and F16) and which, consequently, were relevant to answer the research on technological knowledge flows. From the results of this stage, companies located at Vale dos Vinhedos, associated to Aprovale, were defined as an adequate group for the intended research.

- Stage 2: The data-gathering instrument for the survey research was constituted based on the exploratory stage results, on research instruments used by Giuliani (2005a) and by Ruffoni (2009). After the structuring of the research instrument, the pre-test phase of the questionnaire began, and was applied to companies of different sizes. As soon as the questionnaire was validated, the research instrument was organized in an online tool.

- Stage 3: on the research's execution stage, which occurred from June to July 2013, Aprovale was contacted and asked for a list of associated companies, which contained 29 wineries listed. Upon verification of the companies to be researched, the respondents were identified, which were designated by the specialists interviewed on Stage 1 or suggested by the Association itself, were identified, always considering the advice that the 'interviewed' respondents were responsible for the development process and improvement of products in the company. This way, in general, respondents were either owners or winemakers of the wineries. It was performed, then, firstly, a phone call to the companies, in which it was aimed to contact previously nominated people and explain the study's objective. Next, the questionnaire was sent and answers were monitored through the platform. Out of 29 companies from Aprovale, four did not fit the research's purposes, as exposed in Table 1. In total, 18 questionnaires were answered, which gives the research a response rate of $72 \%$.

- Stage 4: due to the relevance of investigating the whole population of individuals in studies that use the social network methodology (in this case, the 25 wineries), considering specially the whole-network proposal, in May 2014 a new attempt on interview with specialists from non-respondent firms occurred, though none of the seven companies was willing to participate. It was decided, then, to start the verification of the importance of these nonrespondent ones in the cluster, considering the technological leadership and the size. From interviews performed in the exploratory stage with specialists from the sector, as previously mentioned, it was identified that: 1) companies that stood out for their size were in the investigated sample, except for one that did not answer the research and was codified as 'Fnr2' and 2) other six non-respondent companies were characterized in the exploratory stage for their lower positions in the cluster, when questions regarding technological leadership were considered.

Table 1. Definition of researched sample

\begin{tabular}{lc}
\hline \multicolumn{1}{c}{ Definition of researched survey } & Number of Companies \\
\hline Population of companies associated to APROVALE & 29 \\
Did not produce wine & 1 \\
Were not active anymore & 1 \\
Did not start the commercialization of their products yet & 1 \\
Do not commercialize developed products, using them exclusively for teaching activities & 1 \\
Population that fits in the research's objectives & 25 \\
Refused to take part in the research & 7 \\
Final Sample & 18 \\
\hline
\end{tabular}

Source: Elaborated by the authors. 
After the data gathering was finished, the stage of exam and discussion of results based upon descriptive statistics and social network analysis started. For the drawing of networks and indicators calculation, Ucinet software was used, as presented in the following.

\section{Results discussion}

This section aims to discuss results collected in the survey research. Firstly, respondent wineries' main characteristics are presented in a straightforward way, so that, next, results belonging to knowledge and information flows are discussed.

As applicable to wineries' characterization, it is observed that all of them: 1) are fine wine producers and 2) considering their foundation period, two are less than 10 years old, seven are between 10 and 20 years old and the other nine are more than 20 years old. All the respondents have $100 \%$ national capital and commercialize their products, mainly, directly with the client. In relation to production's commercial destiny, 12 firms act only in the national market, while six others also act in the international market. Anyway, for all the respondents, the national market sets itself up as the main destiny of the commercialized products.
Concerning the introduction of innovations to fine wines' national and international market, $72 \%$ of companies consider themselves average when compared to other companies located at Vale dos Vinhedos. Only 28\% answered they are superior towards other companies. When the existence of a formally structured department to perform the P\&D activity was analyzed, it was verified that $45 \%$ of the wineries do not perform such activity, while $55 \%$ do, but without a formally structured department.

Regarding the internal development of new products' research activity, it is observed that $78 \%$ of the wineries developed the activity, most of the time, on their own. A total of $18 \%$ of the companies did not perform the activity, while one of the sample's company claimed to develop the activity, usually assisted by other companies or institutions, mentioning, then, its partnership with an Italian winery.

Based on answers related to knowledge and information exchange, networks that demonstrate flows established between firms and institutions were drawn. The connection network among the actors that shows the information flow is presented in Figure 1. To organize this network, answers from all the researched firms related to the following question: "does your company interact with the listed companies to exchange information regarding new commercial

Figure 1. Information flow among all respondent companies

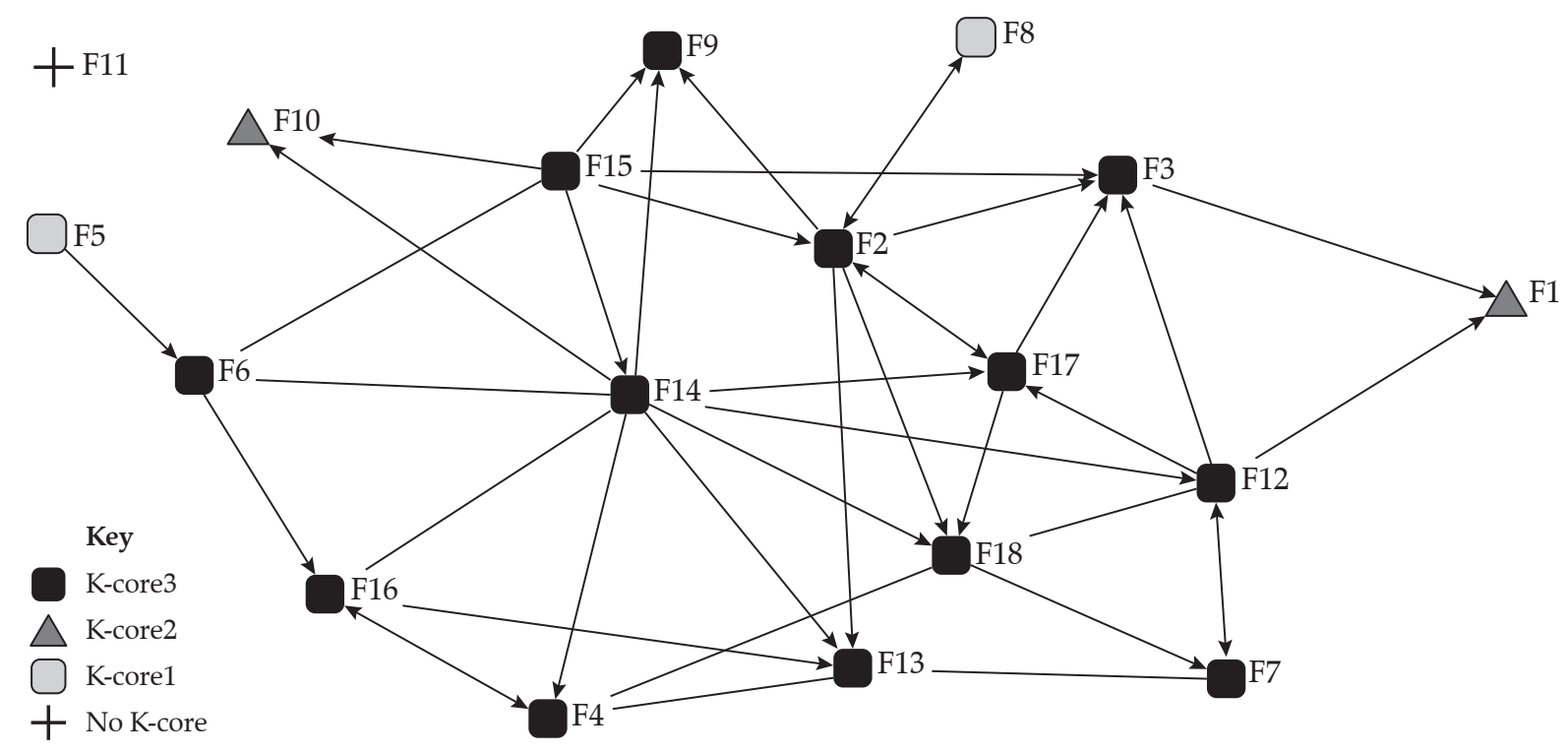

Source: Data from the field research in Ucinet 6. 
Figure 2. Knowledge flow among respondent companies

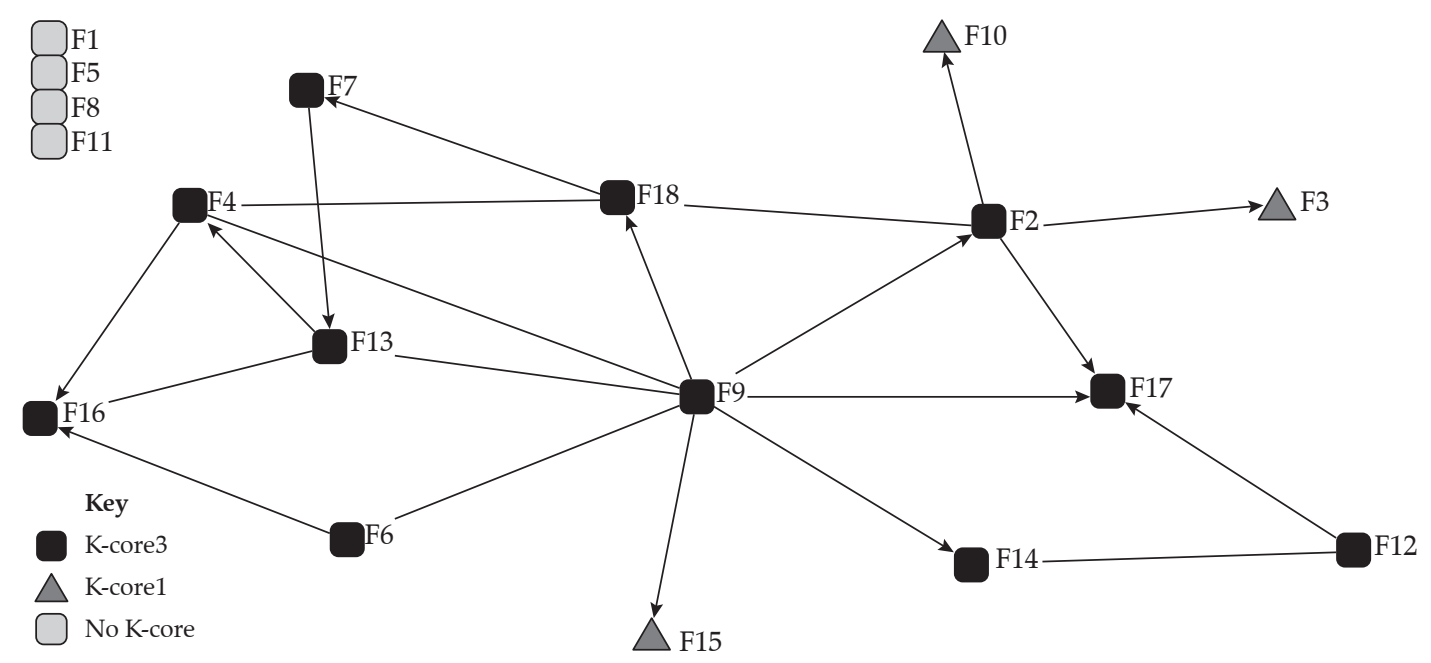

Source: Data from field research at Ucinet 6.

possibilities, new suppliers and new technologies' types?" were considered. ${ }^{11}$

By analyzing the information flow, it is pointed, firstly, that the actors' organization in the network was done according to the k-core tool. ${ }^{12}$ The result of this tool's operation was the companies' grouping according to intensity of interactions numbers they affirmed to establish. Thus, the group identified as "K-core3", described in the key, is the one that gathers actors with more network interactions and is formed by 13 out of 18 respondent firms. Companies characterized by "K-core2" (F1 and F10) have a larger connection among them, but a weak connection with the central group (K-core3). Moreover, companies from "K-core1" (F5 and F8) characterize themselves for having, each, only one connection to the network. At last, it is observed that F11 firm is isolated from the network, which means it informed not to consult or be consulted by any other

11. On the structured questionnaire a tool called roster-recall was applied. It is used when the whole actors' network is known. It consists of the fact that, for each actor from the network, a list with all the members is provided, so that they check with whom they have an association. The researched firms were exposed to a list containing all wineries from Vale dos Vinhedos's cluster, totalizing 29 listed companies. However, they could also check companies outside the ones on the list, situated in Brazil or abroad.

12. A k-core is a group of nodules that is more connected among them than with other nodules in other k-core. It is a basic tool for network analysis and, in this research's case, it is operated based upon the use of Ucinet software. company from Vale dos Vinhedos for information exchange (that is the reason it is in no K-core).

An important element for the analysis of information flows is tie directions (or tie between the two knots). The meaning of the ties can be unidirectional or bidirectional. As an example, in Figure 2, it shows that F15 interacts, i.e., informed to consult F2, F6, F9, F10 and F14, but these do not interact with F15, which plays a clear cognitive role of "claimant" of information in the network (as previously presented in the Literature Review). On the other hand, F2 company is characterized for being well demanded by other firms, being able to be considered as an information offering party. Finally, it is worth to stress that when there is tie absence, it is said that the knot is loose in the network, since this actor does not establish any type of relation with other actors in the network, which is the case of F11.

Companies were also questioned about technological knowledge exchange they establish among themselves. The network in Figure 2 represents the knowledge flow and was structured based upon the following question: "when the company finds itself in a critical situation and needs the technological aid (technological knowledge), in which listed company (ies) does it seek aid?"13

The actors in Figure 3 are also organized by the K-core tool. Equally as observed in the information

13. In the same way that occurred with the information exchange network, the roster-recall tool was operated for data collection concerning knowledge flow among companies from the cluster. 
Figure 3. Information flow among all respondent and mentioned companies

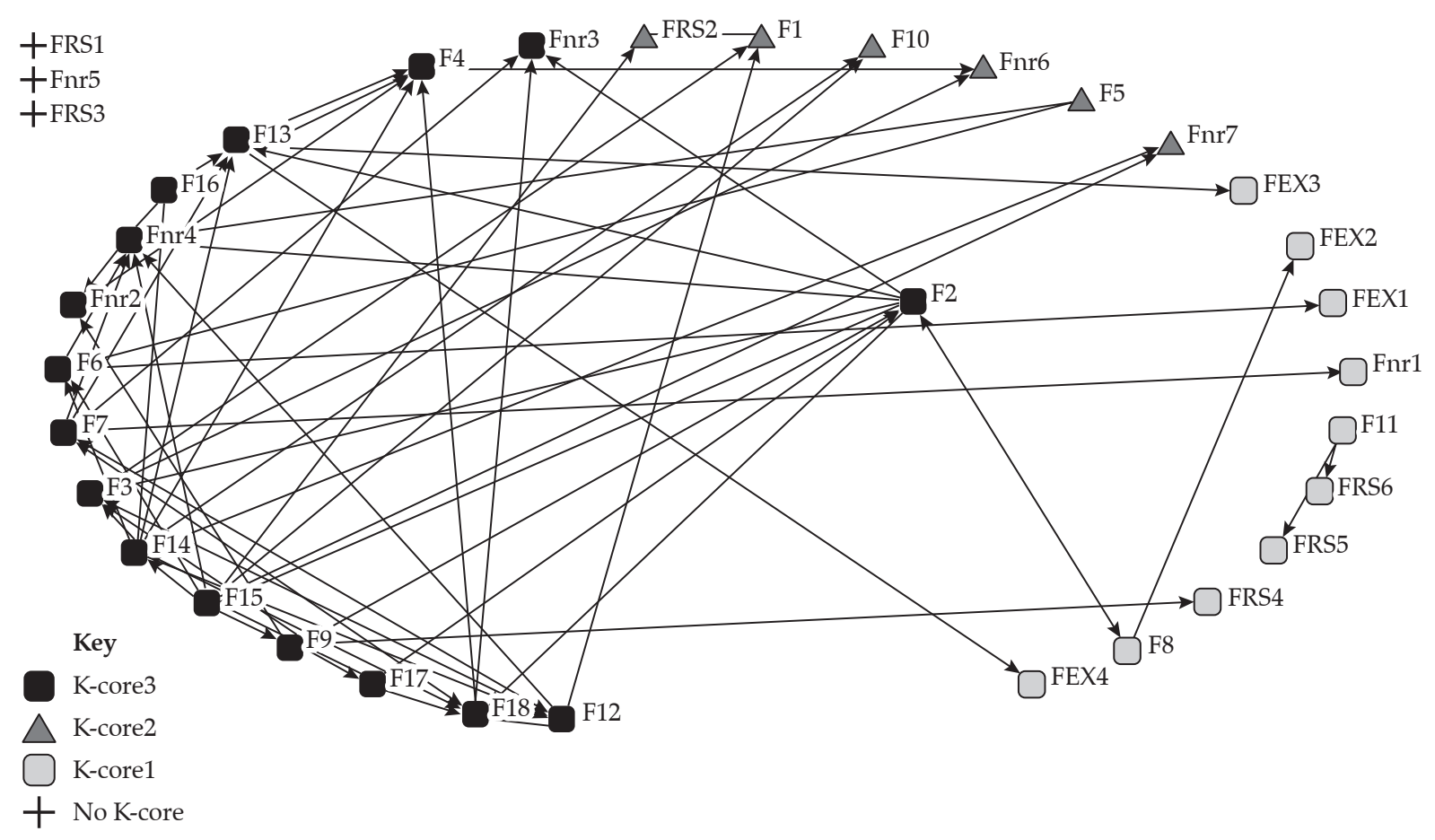

Source: data from field research at Ucinet 6.

exchange network, there is a larger number of companies in "K-core3" category, which represents the central group that establishes great part of network relations and is formed by 11 companies (out of 18): F2, F4, F6, F7, F9, F12, F13, F14, F16, F17 and F18. The companies characterized by "K-core1" (F3, F10 and F15) establish a major connection among them, but a weak connection with the central group. Finally, the group denominated "no K-core" (F1, F5, F8 and F11) is the one composed by companies that declared neither to consult nor to be consulted for knowledge exchange. It is verified that this number of isolated companies increases regarding the one observed on the information network.

By comparing Figures 2 and 3, it is observed, through the ties established among the actors, that the information exchange network is thicker than the one established for knowledge exchange. It corroborates the results from other empirical studies, which also identified such difference in the knowledge and information exchange dynamic among firms from the same productive segment and local agglomeration, as discussed in the section review of literature. In a certain way, it is difficult to understand such distinction, since the firms, for competing with each other, are willing, above all, to supply information concerning equipment and raw material suppliers, for example, rather than information regarding technological knowledge.

It is relevant to observe that, besides networkdensity differences, firms do not necessarily play the same roles in both drawn flows. For example, F9 firm's placement is quite distinct in the two figures. It is central in the knowledge network, playing an exclusive cognitive role of "claimant" knowledge (observed by the arrows' direction). On the other hand, in the information network, this firm is less connected and plays the role of information "source". It can also be observed through the large number of isolated firms in the knowledge network, while only F11 informed not to exchange information with the group of firms from the cluster.

For a most precise analysis of the networks presented, position and structure indicators ${ }^{14}$ were

14. On the social networks analysis method, there are different indicators that can be calculated. The most adequate indicators' choice is guided by the network's size and by the type of network in analysis. In this research's case, the chosen indicators are those considered relevant for the small dimensioned networks and in case of the use of the whole-network method, as previously explained. 
580 - Does the Geographical Proximity Matter in Knowledge and Information Flow? A study about wine cluster in the Southern region of Brazil

calculated based on the social network analysis method (HANNEMAN and RIDDLE, 2005). Structure indicators calculated were: density, geodetic distance and reciprocity. The position indicators were: connectivity, hierarchy and efficiency. Calculation results are presented in Table 2 .

A network's density is defined by the sum of all existent connections divided by the theoretical number of possible connections. In information flow's case, density is 0.1536 and knowledge is 0.0686 , meaning that $15.36 \%$ of possible connections are present in the first and $6.86 \%$ in the second, denoting a low density of analyzed networks, especially in the knowledge one. Besides, there is a significant dispersion of answers, considering that standard deviations are relatively high.

Geodetic density represents a number of relations in the shortest path possible between two nodules, representing the most efficient connection between two actors. In this indicator's case, the average distance in the information network is 2.091 and in the knowledge network it is 1.424 . It means that the most efficient connection between two actors is, in average, reached with less than three contacts (actors) in the information network and less than two contacts in the knowledge network. When the network is not very dense, the geodetic distance is usually small.

The reciprocity among actors in the network presented distinct results: in the knowledge flow it is null $(0 \%)$ and in the information flow it is $27.03 \%$, i.e. a little less than $1 / 3$ of the actors have mutual connections in information exchange. It is considered that there is little reciprocity, and it can be observed in Figure 2, for example, through the bidirectional flows of $\mathrm{F} 2$ with companies F17, F18, F9, for instance, as well as the one from company F12, which keeps bidirectional flow with company F7.

Rooting or position indicators were calculated through Krackhardt's method and are three: connectivity, hierarchy and efficiency. Again, difference among networks is identified. Connectivity indicator's results are quite different and demonstrate a higher connectivity in the information network than in the knowledge one. Connectivity in the last one is very low, reflecting on the amount of companies that affirmed not to participate in the knowledge flow (four isolated nodules in Figure 3).

In the knowledge network there is a superior hierarchy than in the information network's one, indicating that a lower quantity of actors concentrates the knowledge exchange. The information network, differently, has an inferior hierarchy index, informing that information exchange occurs in a less centralized way and corroborates with the existence of some reciprocity in this network. The knowledge network's efficiency index, which means the existence of exchange with only one central actor, is also superior to the information network's one, highlighting that

Table 2. Position and structure indicators of knowledge and information networks

\begin{tabular}{|c|c|c|}
\hline \multirow{2}{*}{ Structure Indicators } & \multicolumn{2}{|c|}{ Networks } \\
\hline & Information & Knowledge \\
\hline \multicolumn{3}{|l|}{ Density } \\
\hline Average Value & 0,1536 & 0,0686 \\
\hline Standard Deviation & 0,3606 & 0,2528 \\
\hline Geodetic Distance (average distance among reachable pairs) & 2,091 & 1,424 \\
\hline \multicolumn{3}{|l|}{ Reciprocity } \\
\hline Dyad-based (which proportion of pairs has reciprocal relations among them?) & $27,03 \%$ & $0 \%$ \\
\hline \multirow{2}{*}{ Position Indicators } & \multicolumn{2}{|c|}{ Networks } \\
\hline & Information & Knowledge \\
\hline \multicolumn{3}{|l|}{ Krackhardt } \\
\hline Connectivity & 0,8889 & 0,5948 \\
\hline Hierarchy & 0,6609 & 1,0000 \\
\hline Efficiency & 0,8250 & 0,8970 \\
\hline \multicolumn{3}{|l|}{ Centrality (Freeman method) } \\
\hline Average (out and in degree) & 2,611 & 1,167 \\
\hline In-degree (who is consulted) & $14,88 \%$ & $11,42 \%$ \\
\hline Out-degree (who consults) & $39,79 \%$ & $42,56 \%$ \\
\hline
\end{tabular}

Source: Elaborated by the authors based on data from field research. 
there are higher quantities of central actors in the information network than in the knowledge network.

Lastly, in terms of centrality calculation, the maximum of possible centrality is considered represented by hypothetical structures from a star network - as reference. In the information network's case, network's centrality degree is $14.88 \%$ for consulted actors (in-degree) and 39.79\% for actors that consult it (out-degree), showing that there is a different distribution of power in the network. For the knowledge network, degrees are: $11.42 \%$ for the consulted ones and $42.56 \%$ for those that consult technological knowledge, observing a higher centrality. These results also show that the analyzed networks are very different from a star network, in which there is a single central actor that connects (or controls) the others, and this result can be considered adequate, since literature points out that a diversity of contacts contributes for the actors' exchange and learning process on site, as observed by Morrison and Rabellotti (2005a).

Networks presented to this point represent exclusively established relations among respondent companies to the survey research, i.e. 18 firms. It was chosen to firstly present these networks, since it is understood that they represent the essentiality of horizontal relations for information and knowledge exchange among firms from the same productive segment - wineries - and located in the same cluster - Vale dos Vinhedos. However, these relations do not represent the totality of information and knowledge flows performed by firms, since they claimed to also relate to other cluster's internal companies (nonrespondents), external companies and to support institutions.

Considering that, the figures set out below present the expanded relations of correspondent companies. It is appropriate to stress two aspects: 1) for these networks, position and structure indicators were not calculated, as it was done before, since they become meaningless the moment mentioned actors are aggregated, but 'non-respondent'; and 2) mentioned firms from outside the cluster are companies from the same productive segment, i.e. other wineries, not being part of this research's object the relation with clients and suppliers, for example. This settled, here the delimitation of the work that consists in understanding horizontal relations, exclusively, is reinforced.
Starting by the information flow, Figure 3 presents the existent relations among all respondent companies and all the others that were mentioned (respondent or not).

The information assigned to actors from the flow presented in Figure 3 was performed again according to the k-core tool. Once again a central core (K-core3) and peripheral cores (K-core2, K-core1) are perceived. It is important to highlight that there are groups of firms in the Figure: a) the ones found in the cluster are respondent, represented as F1 to F18; b) the ones found in the cluster, but 'non respondent' are identified as Fnr1 to Fnr7. They are present in the flow for being mentioned by the respondent ones; c) the ones found out of the cluster, but on the geographical boarders of the state of Rio Grande do Sul, identified as FRS1 to FRS6 and d) the ones located out of the cluster and the country, identified as FEX1 to FEX4. Therefore, in this Figure, it is possible to observe that firms benefit from relations that geographically extrapolate the cluster, counting on firms located in RS or abroad, which denotes a certain degree of openness of the cluster to external information sources. The same can be verified for the knowledge flow, even though this last one presents itself again less dense than the information flow. This can be observed comparing Figures 3 and 4 .

In Figure 4, a smaller number of actors and ties are observed in relation to Figure 3, confirming the characteristic of firms' larger dynamic for information exchange than for knowledge exchange. It is also important to observe that the four firms found abroad (identified as ' $F E X^{\prime}$ ) and that are consulted in the information network are not present in the knowledge network, which counts only with a consulted foreign company (FEX 5) and is positioned at the network's outskirts, since only company F8 consults it. It is concluded, then, that the cluster's openness to external firms in the knowledge exchange is smaller than the one observed in the information one. Such fact seems justifiable when it is considered that knowledge exchange demands higher relational proximity (social and cultural) ${ }^{15}$ and this, although not exclusive to agents found in the same territory, has the geographical proximity as an enabler.

15. For a discussion on relational proximity (social and cultural) concept, see, for instance, Maskell and Malmberg (1999), Amin and Cohendet (2004) and Giuliani (2005b). 
582 Does the Geographical Proximity Matter in Knowledge and Information Flow? A study about wine cluster in the Southern region of Brazil

Figure 4. Knowledge flow among all respondent and mentioned companies
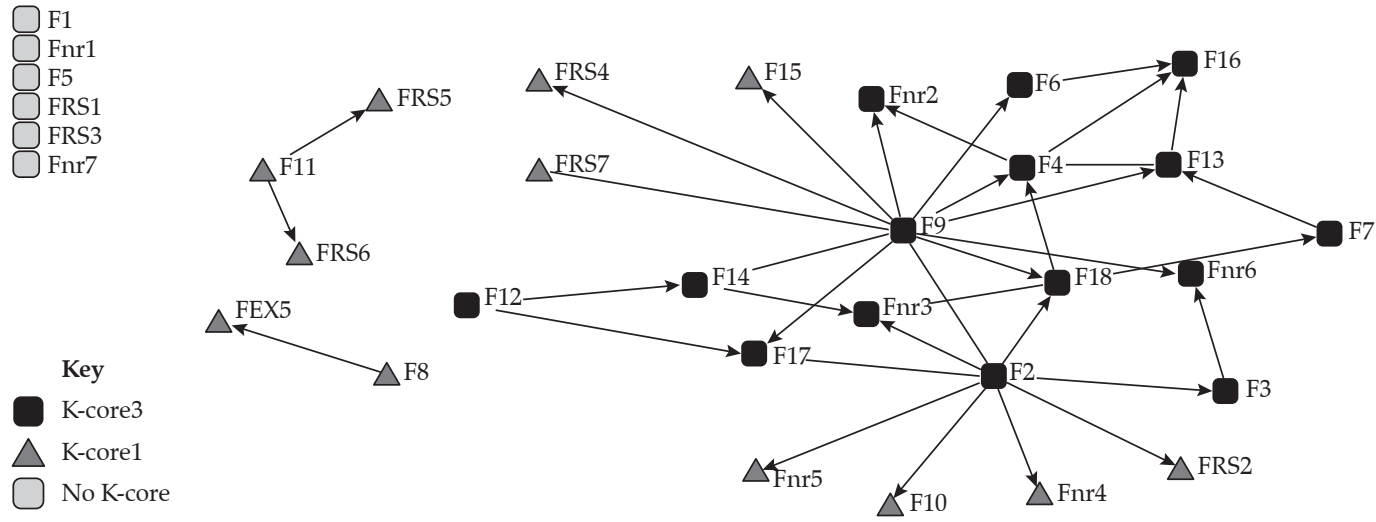

Source: Data from field research at Ucinet 6.

Figure 5. Knowledge flow among all respondent and mentioned companies and institutions

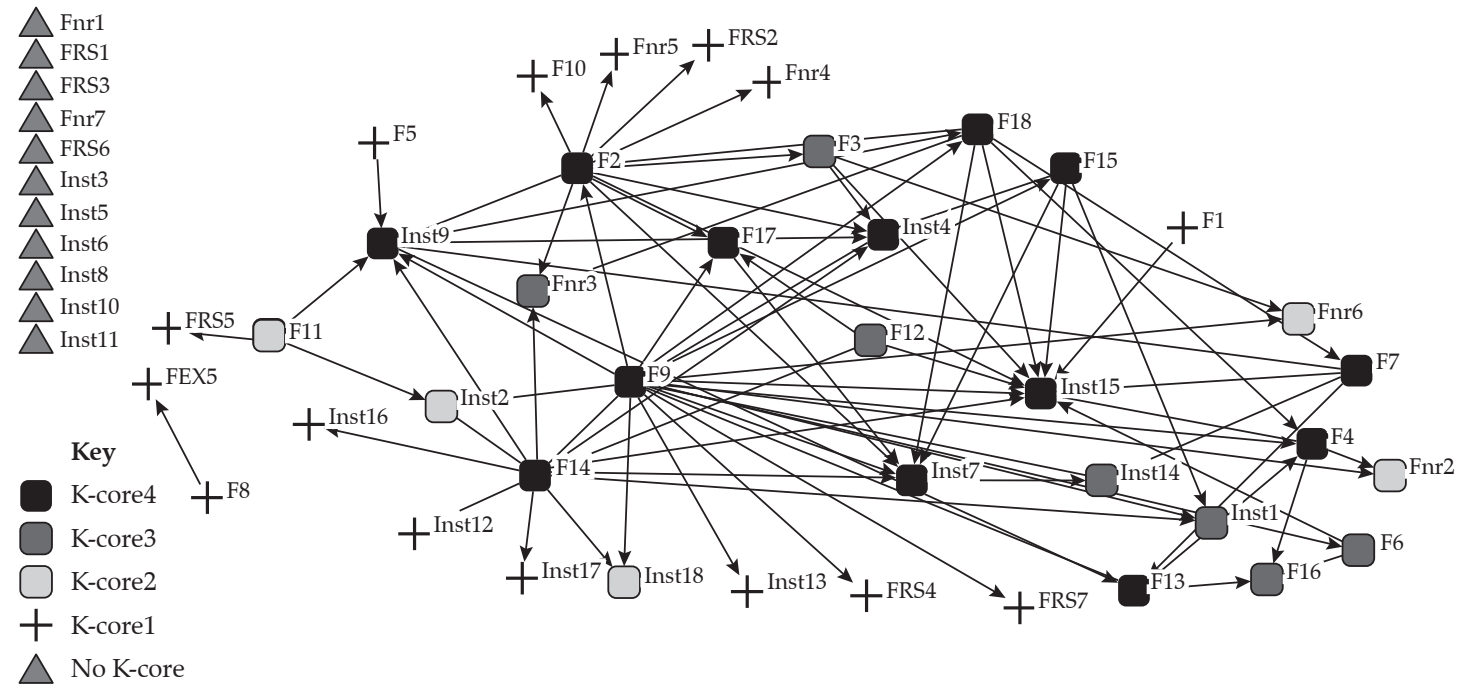

Source: Data from field research at Ucinet 6.

It is suited to stress the central positions and the ties' intensity that companies F9 and F2 have in the knowledge flow, reinforcing the conception that companies play heterogenic roles. Such characteristic will be explored later on, when the cognitive roles' identification of each firm in the knowledge network is discussed. Figure 5 presents an enlarged knowledge flow for relations also established with institutions.

As it can be observed in Figure 5, once inserted, institutions reach an important feature in the network. Among all institutions mentioned by respondent companies, it is Embrapa Grape \& Wine ${ }^{16}$ (I15) the

16. The Brazilian Agricultural Research Corporation (Embrapa) Grape \& Wine is located in Bento Gonçalves, one that presents most connections, being extremely demanded by many researched firms. It is, therefore, considered an important information source in the network in analysis. This happens because it is known as the greatest research institution of vitiviniculture in the country, docking technological solutions that have a significant impact on the wineries' competitiveness. The second place features Aprovale (19), the association that congregates fine wine producers from Vale dos Vinhedos, being responsible for the control of products protected by Geographic Indication of Vale

in RS and as other Embrapa's units spread across national territory oriented to research and services, ties itself to the Ministry of Agriculture and Supply. 
dos Vinhedos and management of this brand. In third place, in number of connections, is Enology Brazilian Association - ABE (I4), a class entity that, besides representing the winemakers, seeks to offer courses, services and solutions to improve these professionals in Brazil. In fourth place is Brazilian Service of Support to Micro Business - Sebrae (I7), which is particularly dedicated to support the management improvement of small businesses. In sequence, with an inferior number of connections, there are the following institutions: Vitiviniculture Brazilian Union - Uvibra (I2); Wine Brazilian Institute - Ibravin (I1); Technical Assistance and Rural Development Company - Emater (I14) and Caxias do Sul University - UCS (I18). Rio Grande do Sul
Federal Institute - IFRS, Bento Gonçalves campus (I17), although known as an important institution for labor qualification for the wine sector, little is it highlighted as a knowledge source. Such result corroborates the work of Farias and Tatsch (2014) that points out that wineries from this region of RS establish with IFRS's Bento Gonçalves Campus a relation purely of hiring trainees and former students of its courses, existing a clear gap in the relation of this institution with actors from the Cluster, especially regarding research and extension activities. In order to better understand firms' positions in the knowledge network, Table 3 was elaborated, informing characteristics of some attributes of the firm and its cognitive role in the knowledge network.

Table 3. Attributes of firms in knowledge network

\begin{tabular}{|c|c|c|c|c|c|c|c|c|c|}
\hline$\stackrel{n}{\Xi}$ & 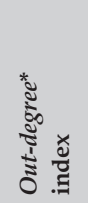 & 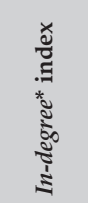 & 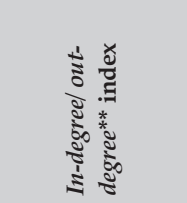 & 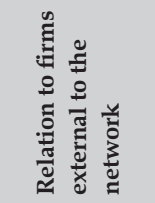 & : & 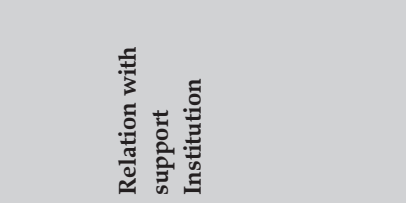 & 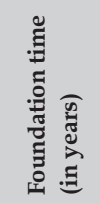 & 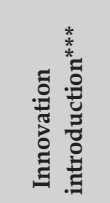 & 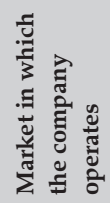 \\
\hline F2 & 23.529 & 5.882 & 0,25 & FRS2 & Absorber & Inst $2,4,7,9$ e 15 & 10 to 20 & Average & National \\
\hline F12 & 11.765 & 0.000 & Only out-degree & - & Claimant & Inst15 & +20 & Average & National \\
\hline F9 & 47.059 & 0.000 & Only out-degree & FRS4 e FRS7 & Claimant & Inst $1,2,4,7,8,9,13,14,15$ and 18 & +20 & Average & $\begin{array}{c}95 \% \text { Nat. } \\
5 \% \text { Int. }\end{array}$ \\
\hline F14 & 0.000 & 11.765 & Only in-degree & - & Source & Inst $1,2,4,7,9,12,14,15,16,17$ and 18 & +20 & Average & National \\
\hline F10 & 0.000 & 5.882 & Only in-degree & - & Source & Inst17 & 10 to 20 & Average & National \\
\hline F15 & 0.000 & 5.882 & Only in-degree & - & Source & Inst $1,4,7$ and 15 & 10 to 20 & Superior & $\begin{array}{l}80 \% \text { Nat. } \\
20 \% \text { Int. }\end{array}$ \\
\hline F16 & 0.000 & 17.647 & Only in-degree & - & Source & - & +20 & Superior & $\begin{array}{c}70 \% \text { Nat. } \\
30 \% \text { Int. }\end{array}$ \\
\hline F17 & 0.000 & 17.647 & Only in-degree & - & Source & Inst 4,7 and 9 & +20 & Average & National \\
\hline F3 & 0.000 & 5.882 & Only in-degree & - & Source & Inst 4 and 15 & 10 to 20 & Average & National \\
\hline F1 & 0.000 & 0.000 & - & - & Isolated & Inst 15 & +20 & Average & National \\
\hline F11 & 0.000 & 0.000 & - & FRS5, FRS6 & Isolated & Inst 2 and 9 & +20 & Average & $\begin{array}{l}55 \% \text { Nat. } \\
45 \% \text { Int. }\end{array}$ \\
\hline F8 & 0.000 & 0.000 & - & FEX5 & Isolated & - & 10 to 20 & Average & National \\
\hline F5 & 0.000 & 0.000 & - & - & Isolated & Inst9 & +20 & Average & National \\
\hline F13 & 11.765 & 11.765 & 1,00 & - & Reciprocal & Inst9 & -10 & Superior & National \\
\hline F18 & 11.765 & 11.765 & 1,00 & - & Reciprocal & Inst 7,9 and 15 & 10 to 20 & Average & National \\
\hline F7 & 5.882 & 5.882 & 1,00 & - & Reciprocal & Inst 9,14 and 15 & -10 & Superior & National \\
\hline F6 & 5.882 & 5.882 & 1,00 & - & Reciprocal & Inst15 & 10 to 20 & Average & $\begin{array}{c}80 \% \text { Nat. } \\
20 \% \text { Int. }\end{array}$ \\
\hline $\mathrm{F} 4$ & 5.882 & 17.647 & 3,00 & - & Transmitter & Inst15 & +20 & Superior & $\begin{array}{c}90 \% \text { Nat. } \\
10 \% \text { Int. }\end{array}$ \\
\hline
\end{tabular}

Notes: * The out-degree measures in which extension a firm consults other firms from the cluster technological knowledge and the in-degree measures in which extension a firm's technological knowledge is consulted by other firms from the cluster. These indexes were calculated with the aid of Ucinet software and are specific indicators of social networks analysis. The logic is to analyze the values in relative terms, comparing them among the firms: higher values inform that the actor consults (out-degree) the network a lot or is very consulted (in-degree). Mathematically in-degree index can be found with $I n=\frac{\sum_{i=1}^{g} d i(n i)}{g-1}$ and out-degree with $I n=\frac{\sum_{i=1}^{g} d o(n o)}{g-1} . * *$ If $\mathrm{I} / \mathrm{O}$ results in a value superior to 1 , it means that the firm is considered 'transmitter' of knowledge; if $\mathrm{I} / \mathrm{O}$ results in a value inferior to 1, it means the firm is considered 'absorber' of knowledge; and if $\mathrm{I} / \mathrm{O}$ results in a value around 1, it means that the firm is involved in a reciprocal exchange. *** It refers to the answer the firms gave for the following question: "concerning introduction of innovations in the fine wines' national and international market, how does the company consider itself regarding other companies located at Vale dos Vinhedos region?" a) inferior to average; b) average or c) superior to average". The information provided in the answers is understood as an approach to the firm's 'innovative performance'.

Source: Elaborated by the authors. 
584 Does the Geographical Proximity Matter in Knowledge and Information Flow? A study about wine cluster in the Southern region of Brazil

Information in Table 3 is ordered by the firms' cognitive role. Different cognitive roles regarding knowledge exchange among firms from the cluster can be observed.

The cognitive roles are identified by the relation between in-degree and out-degree index, as presented on the fourth column of Table 3. The firms' identified cognitive roles were:

- Absorber: it has an I/O index lower than 1. It is an actor that consults and is consulted in the knowledge network, but it requests more technological knowledge from other firms than it is requested. This is the case of company F2, which also consults an extra-local company (a company located in RS, identified as FRS2) and support institutions present in the cluster;

- Claimant: it is the firm that only consults and is not consulted, i.e. it resorts to the group of firms from the site to acquire technological knowledge, but is not requested as a knowledge source. These firms are F12 and F9. It is important to highlight $\mathrm{F9}^{\prime}$ s role in the knowledge flow, since it has the highest index of out-degree from the cluster. It is understood that these claimant firms are precisely firms with high capacity of absorption of external knowledge. Furthermore, they also consult support institutions present on site. F9 also seeks technological knowledge in two companies located extra-cluster, in RS. Although they are connected with extra-local companies, they do not play the role of technological gatekeepers, since they are exclusively claimants of knowledge, not being consulted by other firms from the site. Therefore, they do not disseminate the knowledge they absorb;

- Source: it is the firm that is only consulted and does not consult other firms from the cluster on technological knowledge. It is the largest group of firms identified in this research, six companies in total, i.e. $1 / 3$ of the sample. These are: F10, F15, F16, F17, F3, F14. It is a group of actors that does not consult any extra-cluster firm, not playing, in this sense, the role of technological gatekeeper. The majority consults support institutions.

- Isolated: do not participate in the knowledge network, i.e. do not consult or are consulted by firms from the cluster. In total they are four: F1, F8, F11 and F5. These are firms that are connected with extra-cluster companies (FRS5, FRS6 and FEX8) and with support institutions. Also, they stand out for being the oldest (most of them are more than 20 years old). A possible explanation for this type of behavior may be related to the type of product elaborated and/ or to the innovativeness degree of products and processes introduced by firms. Future research may advance on understanding these aspects.

- Reciprocal: in the aggregate there are four companies - F13, F18, F7 and F6 - that have a balanced position of knowledge supply and demand on site. Besides relations established with other wineries from the site, they also interact with support institutions; and, lastly,

- Transmitter: it is the firm that has the I/O index superior to 1 , meaning that it consults and is even more consulted by other local companies. Only F4 has this role in the identified knowledge network. In the typology presented by Giuliani and Bell (2005) there still are some types of firms that were not identified in the knowledge network established among other wineries at Vale dos Vinhedos. These are:

- Technological gatekeepers: the ones that are in a central position in the network in terms of knowledge transference to other local firms and that are also strongly connected to external knowledge sources. The hypothesis that emerges from this statement is that, because firms used it relatively more intensively, regarding exchanges that are established among them, support institutions as knowledge sources, these may be playing the role of "expanding" the access to external knowledge in the cluster.

- Active mutual exchangers: they are firms that form the central part of the cluster's knowledge system, maintaining strong internal and external relations, though they are less connected to extra-cluster agents than the technological gatekeepers; this role could be played by the group named 'reciprocal', in case they had a connection with external sources, which does not occur;

- Weak mutual exchangers: they are firms similar to the active mutual exchangers, because they 
are relatively well connected to knowledge sources external to the cluster and because they are in a balanced position of supplying and absorbing. However, they are less connected to companies from the cluster; and, lastly,

- External stars: they are the ones that establish strong relations to external sources, but have limited relations to intra-cluster knowledge system.

In general, the study's findings here reported reinforce what has been discovered by research in this area: firms establish distinct dynamics in the search for information and knowledge, considering that the active knowledge is less accessed in the relations, whether because it is more specific to the firm or because it is more specialized and, in this way, preserved. Corroborating with it, it is worth highlighting that Morrison and Rabellotti (2005a, 2005b) also identified technological knowledge flow restrict to a community of firms more related in itself. Homogeneous flows were not found among firms from a same cluster. On the other hand, information was more accessible to all. Giuliani (2007) also found similar results both in the wine producer cluster from Chile, as in the one from Italy, because she concluded that information and knowledge flows are significantly different.

Still, in the same way that was stated in other studies, the geographical proximity presents itself as a strong characteristic of horizontal relations established by the firms, as well as relations established with the institutions. Great part of the active firms in the knowledge network seeks or is source for other firms from the own cluster. The institutions consulted by the firms are, essentially, from the site. In addition, lastly, few are the firms that consult companies outside the cluster, indicating the importance of ties established with actors geographically nearer (from the own cluster). When they do, they consult more information than knowledge. In other words, considering the horizontal relations, which are the aim of this study, the technological knowledge that circulates on site is essentially exchanged with firms and institutions from the own territory.

In relation to the gatekeeper's role, Giuliani (2011) had identified as technological gatekeepers firms responsible for acquiring knowledge beyond the cluster's limits and diffusing it internally. Whereas in the case studied here, it was not identified such role in the firms from the cluster. On the other hand, it was verified that some institutions are perceived as important sources for companies; in the same way that Morrison and Rabellotti (2009) identified a supply association of technical assistance to firms as gatekeeper in the cluster of Italian wine studied by them. It may be inferred that Embrapa Grape \& Wine has a similar role on the Brazilian cluster analyzed here that can also be considered as a "gate" of relevant knowledge to be shared on site.

Lastly, conclusion remarks are presented.

\section{Conclusion remarks}

It is important to resume that the objective of this article was to analyze both information and knowledge flows in a particular territory, in the wine cluster from RS, known as an important wine producer in Brazil, as well as these wineries' cognitive role.

In summary, comparing information networks to knowledge networks established among respondent companies, it was observed that there are differences both in structure terms as in positioning terms of the firms. In a general way, a smaller number of firms participated in the knowledge network rather than in the information network. In terms of structure, the knowledge network is more rarefied (lower density) and with null reciprocity; whereas regarding positioning, there is more hierarchy among firms in the exchange for knowledge than in the exchange for information, indicating a larger centrality in the knowledge exchange.

Such results, as it was shown, meet and corroborate with other researches in the same study field of study. This same way, it was also ascertained that geographic proximity matters to information exchange among agents and even to technological knowledge; though there is no homogeneous knowledge flow on site. Besides, it is worth highlighting how relevant support institutions in these flows are, reaching an important role in the innovative processes of the own firms.

Finally, it is understood that it is necessary to deepen the study in order to advance on the identification of aspects that help to explain behavior and role of actors in different flows. It is worth not only complementing the present research based upon 
586 Does the Geographical Proximity Matter in Knowledge and Information Flow? A study about wine cluster in the Southern region of Brazil

face-to-face interviews with the firms and institutions to better qualify their answers, as well as examining other companies' clusters from other productive segments. Moreover, understanding the shaping of relations between intra-cluster institutions and firms becomes an important element for the political planners to rate the dynamic that is established in certain territorial spaces and act in a more assertive way in the consolidation of a support's technological and scientific infrastructure and, this way, promote the social-economic development of a region.

\section{References}

AMIN, A. and COHENDET, P. Architectures of knowledge: firms, capabilities and communities. Oxford: Oxford University Press, 2004.

AMIN, A. and WILKINSON, F. Learning, Proximity and Industrial Performance: an introduction. Cambridge Journal of Economics, v. 23, p. 121-125, 1999.

AUDRETSCH, D. and FELDMAN, M. R\&D spillovers and the geography of innovation and production. The American Economic Review, v. 86, p. 630-640, 1996.

BARABÁSI, A. L. Linked: the new science of networks. Cambridge: Perseus Publishing, 2002.

BATHELT, H., MALMBERG, A. and MASKELL, P. Clusters and knowledge: local buzz, global pipelines and the process of knowledge creation. Progress in Human Geography, v. 28, p. 31-56, 2004.

BOSCHMA, R. Proximity and innovation: a critical assessment. Regional Studies, v. 39, n. 1, p. 61-74, 2005.

CARRINGTON, P. J., SCOTT, J. and WASSERMAN, S. Models and methods in social network analysis. Cambridge: Cambridge University Press, 2005.

COHEN, W. M. and LEVINTHAL, D. A. Absorptive Capacity: a new perspective on learning and innovation. Administrative Science Quarterly, v. 35, n. 1, p. 128-152, 1990.

DOSI, G. The nature of the innovative process. In: DOSI, G. et al. (Eds.). Technical change and economic theory. London: Pinter, 1988.

FARIAS, C. V. S. and TATSCH, A. L. The Brazilian Wine Industry: a case study of geographical proximity and innovation dynamics. Revista de Economia e Sociologia Rural, v. 52, p. 515-532, 2014.

FENSTERSEIFER, J. E. The emerging Brazilian wine industry: challenges and prospects for the Serra
Gaúcha wine cluster. International Journal of Wine Business Research, v. 19, n. 3, p. 187-206, 2007.

DOLOREUX, D. and LORD-TARTE, E. The organisation of innovation in the wine industry: open innovation, external sources of knowledge and proximity. European Journal of Innovation Management, v. 16, n. 2, p. 171-189, 2013.

FENSTERSEIFER, J. E. and RASTOIN, J. L. Cluster resources and competitive advantage: a tipology of potentially strategic wine cluster resources. International Journal of Wine Business Research, v. 25, n. 4, p. 267-284, 2013.

FREEMAN, C. Innovation and growth. In: DODGSON, M. and ROTHWELL, R. (Eds.). The Handbook of Industrial Innovation. Cheltenham: Edward Elgar, 1996, p. 78-93.

GIULIANI, E. Cluster absorptive capability: an evolutionary approach for industrial clusters in developing countries. Paper Presented at the DRUID Summer Conference. Copenhagen, 2002.

When the micro shapes the meso: learning and innovation in the wine clusters. Tese de Doutorado. Science and Technology Policy Research (SPRU). Universidade de Sussex. Brighton, 2005a.

. The Structure of Cluster Knowledge Networks: uneven and selective, not pervasive and collective. DRUID Working Paper N. 05-11, Danish Research Unit for Industrial Dynamics, $2005 \mathrm{~b}$.

. The selective nature of knowledge networks in clusters: evidence from the wine industry. Journal of Economic Geography, v. 7, p. 139-168, 2007.

Roles of Technological Gatekeepers in the Growth of Industrial Clusters: evidence from Chile. Regional Studies, v. 10, n. 45, p. 1329-1348, 2011.

. Clusters, networks and firms' product success: an empirical study. Management Decision, v. 51, n. 6, p. 1135-1160, 2013a.

Network Dynamics in Regional Cluster: evidence from Chile. Research Policy, v. 42, p. 1406-1419, 2013b.

GIULIANI, E. and BELL, M. The Micro-Determinants of Meso-Level Learning and Innovation: evidence from a chilean wine cluster. Research Policy, 34, p. 47-68, 2005.

GIULIANI, E. et al. Who are the researchers that are collaborating with industry? An analysis of the wine sector in Chile, South Africa and Italy. Research Policy, v. 39, p. 748-761, 2010.

HANNEMAN, R. and RIDDLE, M. Introduction to social network methods. Riverside, CA: University of 
California, 2005. Disponível em: <http://faculty.ucr. $\mathrm{edu} / \sim$ hanneman/> .

HOWELLS, J. and BESSANT, J. Introduction: innovation and economic geography: a review and analysis. Journal of Economic Geography, v. 12, p. 929-942, 2012.

JEZIORNY, D. L. Território Vale dos Vinhedos: instituições, indicação geográfica e singularidade na vitivinicultura da Serra Gaúcha. Dissertação de Mestrado. Programa de Pós-graduação em Economia, Universidade Federal de Uberlândia. Uberlândia, 2009.

KOHLS, V. K., SACCO DOS ANJOS, F. and CALDAS, N. V. Mutações no mundo vitivinícola: A indicação geográfica como estratégia de qualificação. Desenvolvimento Regional em Debate, v. 6, p. 41-62, 2016.

LANE, P. J. and LUBATKIN, M. Relative absorptive capacity and interorganizational learning. Strategic Management Journal, v. 19, p. 461-477, 1998.

MALERBA, F. Learning by firms and incremental technical change. The Economic Journal, v. 102, n. 413, p. 845-859, 1992.

MALMBERG, A. and MASKELL, P. The elusive concept of localization economies: towards a knowledge based theory of spatial clustering. Environment and Planning, v. 34, n. 3, p. 429-449, 2002.

MASKELL, P. and MALMBERG, A. Localised learning and industrial competitiviness. Cambridge Journal of Economics, n. 23, p. 167-185, 1999.

MARSHALL, A. Princípios de Economia. São Paulo: Nova Cultural, [1890] 1982.

MORRISON, A. Gatekeepers of Knowledge within Industrial Districts: who they are, how they interact. Regional Studies, v. 6, n. 42, p. 817-835, 2008.

MORRISON, A. and RABELLOTTI, R. Inside the Black Box of "Industrial Atmosphere": knowledge and information networks in an italian wine local system. Quaderno no 97, Dipartimento di Scienze Economiche e Metodi Quantitativi di Università del Piemonte Orientale, July, 2005a.

Knowledge and Information Networks: evidence from an italian wine local system. Working Paper $n^{\underline{o}}$ 174, Centro di Ricerca sui Processi di Innovazione e Internazionalizzazione (CESPRI), Università Commerciale "Luigi Bocconi", September 2005b.

. Knowledge and Information Networks in an Italian Wine Cluster. European Planning Studies, v. 7, n. 17, p. 983-1006, 2009.
MORRISON, A., RABELLOTTI, R. and ZIRULIA, L. When do Global Pipelines Enhance the Diffusion of Knowledge in Clusters? Economic Geography, v. 1, n. 89, p. 77-96, 2013.

NELSON, R. R. and WINTER, S. An Evolutionary Theory of Economic Change. Cambridge (Ma): Harvard University Press, 1982.

NIEDERLE, P. A. and AGUIAR, M. Indicações geográficas, tipicidade e produtos localizados: os novos compromissos valorativos na vitivinicultura do Vale dos Vinhedos. Revista de Economia Agrícola (Impresso), v. 59, p. 21-37, 2013.

PERROUX, F. Les poles de croissance. In: PERROUX, F. L'économie du XXe siècle. Paris: Presses Universitaires de France, 1961, p. 123-242.

RABELLOTTI, R. and SCHMITZ, H. The internal heterogeneity of industrial districts in Italy, Brazil and Mexico. Regional Studies, v. 33, n. 2, p. 97-108, 1999.

RUFFONI, J. Proximidade geográfica e inovação tecnológica de firmas: uma análise para o segmento produtor de máquinas para calçados da Itália e do Brasil. Tese de Doutorado. Instituto de Geociência da Universidade Estadual de Campinas. Campinas, 2009.

RUFFONI, J. and SUZIGAN, W. Influência da Proximidade Geográfica na Dinâmica Inovativa de Firmas Localizadas em Sistemas Locais de Inovação. Revista de Economia, v. 13, n. 1, p. 35-66, 2012.

. Comportamento de firmas industriais em fluxos de conhecimento: uma análise para dois aglomerados produtivos. Estudos Econômicos, v. 45, p. 693-724, 2015.

SACCO DOS ANJOS, F. et al. São as indicações geográficas um instrumento para o desenvolvimento dos territórios? Estudo de caso sobre duas experiências no estado do Rio Grande do Sul. Política \& Sociedade, v. 13, n. 26, p. 163, 2014.

TONIETTO, J. et al. O clima vitícola das regiões produtoras de uvas para vinhos finos no Brasil. In: TONIETTO, J., RUIZ, V. S. and GÓMEZ-MIGUEL, V. D. (Ed.). Clima, Zonificación y Tipicidad del Vino en Regiones Vitivinícolas Iberoamericanas. Madrid: CYTED, 2012. p. 113-143.

WAL, A. L. J. and BOSCHMA, R. A. Applying social network analysis in economic geography: theoretical and methodological issues. Working Paper, Utrecht University, 2007.

WASSERMANN, S. and FAUST, K. Social Network Analysis: methods and applications. Cambridge: Cambridge University Press, 2007. 
